Article

\title{
pKa Determination of a Histidine Residue in a Short Peptide Using Raman Spectroscopy
}

\author{
Brett H. Pogostin ${ }^{1,2} \mathbb{C}^{-}$, Anders Malmendal ${ }^{2}$, Casey H. Londergan ${ }^{1, *(1)}$ \\ and Karin S. Åkerfeldt 1,*iD \\ 1 Department of Chemistry, Haverford College, Haverford, PA 19041, USA; bpogostin@gmail.com \\ 2 Biochemistry and Structural Biology, Department of Chemistry, Lund University, P.O. Box 124, \\ SE-22100 Lund, Sweden; malmendal@gmail.com \\ * Correspondence: clonderg@haverford.edu (C.H.L.); kakerfel@haverford.edu (K.S.Å.)
}

Received: 30 December 2018; Accepted: 22 January 2019; Published: 23 January 2019

check for updates

\begin{abstract}
Determining the $\mathrm{pKa}$ of key functional groups is critical to understanding the $\mathrm{pH}$-dependent behavior of biological proteins and peptide-based biomaterials. Traditionally, ${ }^{1} \mathrm{H}$ NMR spectroscopy has been used to determine the $\mathrm{pKa}$ of amino acids; however, for larger molecules and aggregating systems, this method can be practically impossible. Previous studies concluded that the C-D stretches in Raman are a useful alternative for determining the pKa of histidine residues. In this study, we report on the Raman application of the C2-D probe on histidine's imidazole side chain to determining the $\mathrm{pKa}$ of histidine in a short peptide sequence. The $\mathrm{pKa}$ of the tripeptide was found via difference Raman spectroscopy to be 6.82 , and this value was independently confirmed via ${ }^{1} \mathrm{H}$ NMR spectroscopy on the same peptide. The C2-D probe was also compared to other Raman reporters of the protonation state of histidine and was determined to be more sensitive and reliable than other protonation-dependent signals. The C2-D Raman probe expands the tool box available to chemists interested in directly interrogating the $\mathrm{pKa}$ 's of histidine-containing peptide and protein systems.
\end{abstract}

Keywords: Raman spectroscopy; ${ }^{1} \mathrm{H}$ NMR spectroscopy; vibrational probes; histidine; peptides; proteins; isotopic labeling; deuterium replacement; acid dissociation constant

\section{Introduction}

There is currently a great deal of published data from infrared (IR) probes [1-3]; however, Raman scattering spectroscopy is also gaining traction as a technique for collecting signals from vibrational probe groups. In comparison to IR absorption, complementary selection rules of Raman scattering mean that probe signals can sometimes be more easily observed in Raman than Fourier transform infrared (FTIR) spectroscopy [4]. Additionally, Raman scattering is less sensitive to sample preparation than IR absorption, which often requires experiments to be conducted in $\mathrm{D}_{2} \mathrm{O}$ and in an atmosphere devoid of water vapor and carbon dioxide in order to obtain high-quality spectra.

Carbon-deuterium (C-D) stretches can be employed as a vibrational probe in both FTIR and Raman spectroscopy to report on the molecular environment and dynamics of a selectively deuterated species $[1,5,6]$. One of the first analyses of C-D bands was in the FTIR and Raman spectra of $\mathrm{CD}_{3} \mathrm{OH}$ and $\mathrm{CD}_{3} \mathrm{OD}$ [7], where exchanging a protium for a deuterium (C-H to C-D) caused a shift of $\sim 800 \mathrm{~cm}^{-1}$ for the anti-symmetric and symmetric stretches from $2850-3000 \mathrm{~cm}^{-1}$ to $2050-2350 \mathrm{~cm}^{-1}$, respectively. The C-D stretches of deuterated methanol also reports on whether the methanol oxygen atom is protonated or deuterated. Other early Raman studies of the C-D stretches investigated the spectra of a series of deuterated glycine derivatives $\left(\mathrm{ND}_{3} \mathrm{CD}_{2} \mathrm{COO}^{-}, \mathrm{NH}_{3} \mathrm{CD}_{2} \mathrm{COO}^{-}\right.$, and $\left.\mathrm{ND}_{3} \mathrm{CH}_{2} \mathrm{COO}^{-}\right)$, and 9 deuterated derivatives of stearic acid $[8,9]$. The anti-symmetric stretch around $2300 \mathrm{~cm}^{-1}$ is significantly more intense in the Raman spectrum compared to in the FTIR spectrum. 
Before regular use of the C-D stretch as a vibrational probe in Raman spectroscopy, C-H stretches (ca. 2800-3300 $\mathrm{cm}^{-1}$ ) were employed to investigate the molecular environment and dynamics of lipid membranes [10-14] as well as to study saturated hydrocarbons [15,16]. The C-H stretching region, however, is often obscured by other vibrational modes common in organic compounds, including N-H and O-H stretches (3000-4000 $\mathrm{cm}^{-1}$ ) [8]. C-D stretches, in contrast, appear in a "quiet" window of the Raman spectrum obscured by few other signals save for $C \equiv C\left(2100-2260 \mathrm{~cm}^{-1}\right), C \equiv N$ (2230-2350 $\left.\mathrm{cm}^{-1}\right)$, and cumulative double bonds $\left(C=C=C, C=C=X: 1900-2300 \mathrm{~cm}^{-1}\right)$, which are all possible probes themselves and are very uncommon in natural systems [17-19]. The change from hydrogen to deuterium is also a minimal structural perturbation, especially compared to the already low perturbativity of other vibration probe groups. Thus, the site-specific incorporation of a C-D probe allows for the isolation and investigation of the signal of a specific $\mathrm{C}-\mathrm{H}$ bond without significantly altering the structure of the compound of interest.

The C-D probe has been used to report on a variety of changes in structure, dynamics, and chemical environment. IR spectra of selectively deuterated amino acids have been used as probes of folding and dynamics in proteins $[1,5,6]$. Raman spectra of deuterated methane were used to interrogate organic clathrate hydrate structures that trap methane inside their lattice [20]. Raman C-D stretches have also been used as imaging probes to follow single eukaryotic cell metabolism with high temporal and spatial resolution [21]; by introducing a fully deuterated substrate of interest, such as an amino acid or $\mathrm{D}_{2} \mathrm{O}$, to the cell media, it is possible to probe its uptake and use by observing the Raman C-D stretching region in live cells [22-24].

Calculations by Miller and Corcelli suggested that some C-D frequencies from varying deuterated amino acid side chains could be strongly sensitive to electrostatic changes like protonation and deprotonation events. This idea was consistent with the large experimental response observed classically for deuterated methanol [7] and also suggested that particular C-D stretches might be excellent protonation state sensors (i.e., for histidine residues in proteins) [25].

In this study, we report on the Raman application of the C-D probe to determining the $\mathrm{pKa}$ of the amino acid residue histidine in a short peptide sequence. There is much recent interest in $\mathrm{pH}$-responsive synthetic and natural polymers for applications in biomedicine, such as drug delivery, tissue engineering, and biosensors [26-29], and many cellular proteins behave in a pH-sensitive manner. The ability to determine the $\mathrm{pKa}$ of key functional groups in these processes is especially critical to understanding the $\mathrm{pH}$-dependent behavior of peptides [30]. In this context, histidine is one of the most commonly studied amino acid residues. Due to the near neutral pKa of one of the N-bonded protons on the imidazole side chain of histidine (Figure 1), the histidine residue can act both as a base and, when protonated, as an acid, under physiological conditions. The pKa of histidine is sensitive to its specific chemical environment; for example, it has been found that the pKa values of the histidine residues in the protein phosphatidylinositol-specific phospholipase $C$ vary between 5.4-7.6 as determined by ${ }^{1} \mathrm{H}$ NMR spectroscopy [31]. Thus, to understand $\mathrm{pH}$-responsive peptides and peptide materials, it is necessary to resolve the $\mathrm{pKa}$ of specific histidine residues within these systems.

The deprotonated $\mathrm{N}$ atom in histidine's neutral form is usually the $\delta$-nitrogen on the imidazole side chain (Figure 1): histidine readily exchanges between the $\mathrm{N} \delta-\mathrm{H}$ and $\mathrm{N} \varepsilon-\mathrm{H}$ tautomers, however the $\mathrm{N} \varepsilon-\mathrm{H}$ (shown in Figure 1) tautomer is favored $\sim 4: 1$ at high $\mathrm{pH}$ when not incorporated in an amino acid sequence. Although this ratio is environmentally dependent, for the purposes of this paper we depict this residue in the form of the $\mathrm{N} \varepsilon-\mathrm{H}$ tautomer [32]. The C2-D stretching frequency cannot distinguish between the two singly-protonated tautomers [30]. 


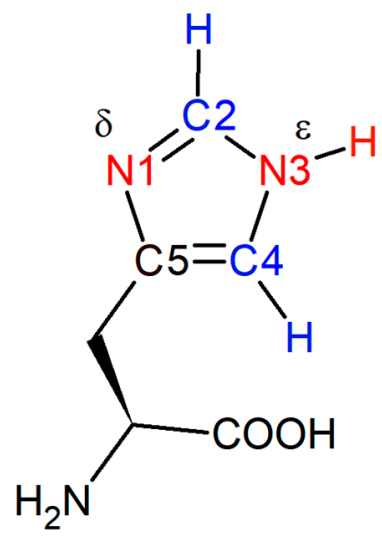

Figure 1. Histidine with carbon atoms 2 and 4 (blue) and $\delta$ - and $\varepsilon$-nitrogen atoms (red) on the imidazole ring. The pKa of the protonated $\delta$-nitrogen is near neutral, and the chemical shifts of protons attached to $\mathrm{C} 2$ and $\mathrm{C} 4$ in ${ }^{1} \mathrm{H}$ NMR spectroscopy are frequently used to determine its $\mathrm{pKa}$.

Traditionally, titration experiments involving ${ }^{1} \mathrm{H}$ NMR spectroscopy have been used to determine the pKa value of amino acids, including that of histidine [31,33-37]; however, alternative methods have also been employed, including capillary zone electrophoresis $[38,39]$ and FTIR using $\mathrm{C}=\mathrm{O}, \mathrm{COO}-$, and N-O stretches of other titratable functional groups [40]. The ${ }^{1} \mathrm{H}$ chemical shifts of the hydrogen atoms attached to $\mathrm{C} 2$ and $\mathrm{C} 4$ (Figure 1) on the imidazole ring are sensitive to the protonation state of the neighboring $\delta$-nitrogen. Upon deprotonation, the $\mathrm{C} 2-\mathrm{H}$ and $\mathrm{C} 4-\mathrm{H}$ proton signals shift from 8.6 to $7.8 \mathrm{ppm}$ and from 7.4 to $7.0 \mathrm{ppm}$, respectively [36]. The pKa value of the histidine residue is extracted by plotting the chemical shift as a function of $\mathrm{pH}$ and fitting the data to a sigmoidal curve. ${ }^{1} \mathrm{H} \mathrm{NMR}$ spectroscopy, however, is limited to soluble peptides and proteins with relatively small molecular masses compared to many natural and artificial biomolecules. For larger molecules and aggregating systems, NMR signals are lost due to line broadening as a consequence of structural heterogeneity and/or slow tumbling on the NMR time scale. While solid-state NMR poses a possible alternative option for recovering signals from such samples, the resolution from such measurements largely excludes determination of protonation states.

Raman spectroscopy offers a promising alternative due to its relative insensitivity to sample preparation and its ability to resolve signals from arbitrary phases. The imidazole C4-C5 and C4-N3 stretches, and potentially the $\mathrm{C}-\mathrm{H}$ stretches, can report on the protonation state of the sidechain of histidine [41,42]. Although these indicators are useful for small molecules like methylimidazole, it is likely that the Raman spectra of larger and more complex peptide sequences would be too crowded to provide the $\mathrm{pKa}$ of a single residue with any great clarity. In 2013, Hoffman et al. published an alternative method to determine the pKa of histidine using the C2-D stretch in Raman spectroscopy [30]. The C2-D Raman stretch is clearly sensitive to the protonation state of the $\mathrm{N}$ atoms on imidazole: in the doubly protonated state it appears at $2390 \mathrm{~cm}^{-1}$, and then shifts $40 \mathrm{~cm}^{-1}$ to $2350 \mathrm{~cm}^{-1}$ upon deprotonation (Figure 2). This shift was monitored as a function of $\mathrm{pH}$ and used to report the pKas of L-carnosine, methylimidazole, and histidine individually in solution. The goal of this study was to further develop and optimize this method and assess if the pKa of histidine could be determined in a more complex system, such as the end-capped peptide Ac-NH-histidine-valine-aspartic acid-CONH (abbreviated HVD), which is the beginning of a $\mathrm{pH}$-dependent hydrogel-forming sequence [26]. 


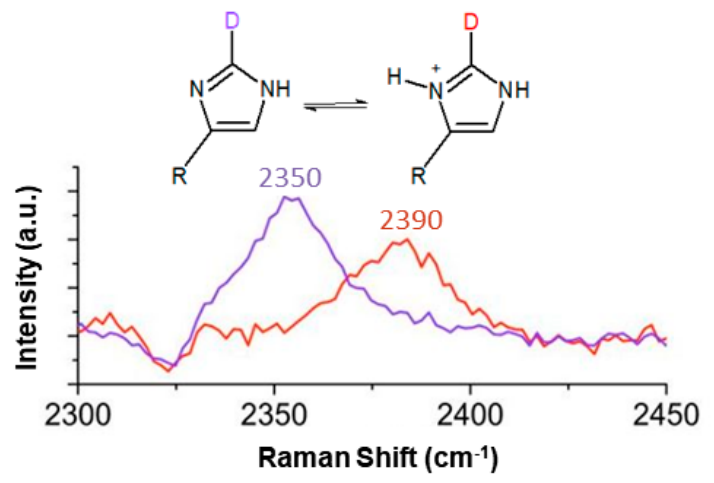

Figure 2. The C2-D Raman stretch from the imidazole sidechain of histidine is sensitive to the protonation state of the neighboring $\mathrm{N}$ atoms. The protonated and deprotonated imidazole ring C2-D stretches were observed at $2390 \mathrm{~cm}^{-1}$ (red curve; $\mathrm{pH} 2.5$ ) and $2350 \mathrm{~cm}^{-1}$ (purple curve; $\mathrm{pH} 9.8$ ), respectively. Adapted with permission from [30]. Copyright 2013 American Chemical Society.

\section{Results}

\subsection{HVD Deuterium Exchange Reaction}

Deuterium incorporation at $\mathrm{C} 2$ of the imidazole ring of HVD was accomplished through a previously reported exchange reaction (Figure 3) [30]. The peptide was dissolved in $\mathrm{D}_{2} \mathrm{O}$ to $\sim 10 \mathrm{mM}$ concentration, corrected to $\mathrm{pH} 8$ with $\mathrm{NaOD}$, heated at $50{ }^{\circ} \mathrm{C}$ for three days, then lyophilized. Readily exchangeable protons, such as the amide backbone $\mathrm{N}-\mathrm{H}$ and the O-H of the carboxylic acid sidechain of the aspartic acid, were then back-exchanged via the addition of $0.01 \mathrm{M} \mathrm{HCl}$, followed by re-lyophilization. Mass spectrometry analysis of the post-exchange tripeptide confirmed quantitative exchange of hydrogen to deuterium without further persistent deuteration at other positions, as verified by the increase of the peptide mass by 1 Dalton. Raman spectroscopy further confirmed the back exchange of hydrogen for deuterium at all readily exchangeable positions via the absence of broad $\mathrm{N}-\mathrm{D}$ and O-D stretches around $2400 \mathrm{~cm}^{-1}$ that could overlap with the sharper C2-D stretch in the aqueous Raman spectrum.

The deuterium probe in $\mathrm{H}(\mathrm{C} 2-\mathrm{D}) \mathrm{VD}$ was stable over the biologically relevant $\mathrm{pH}$ of 4-10, and similar in stability to C2-deuterated histidine, as previously reported [30]. No back exchange of C2-D to $\mathrm{C} 2-\mathrm{H}$ was observed at neutral $\mathrm{pH}$ when stored at $5-21^{\circ} \mathrm{C}$ for several months.

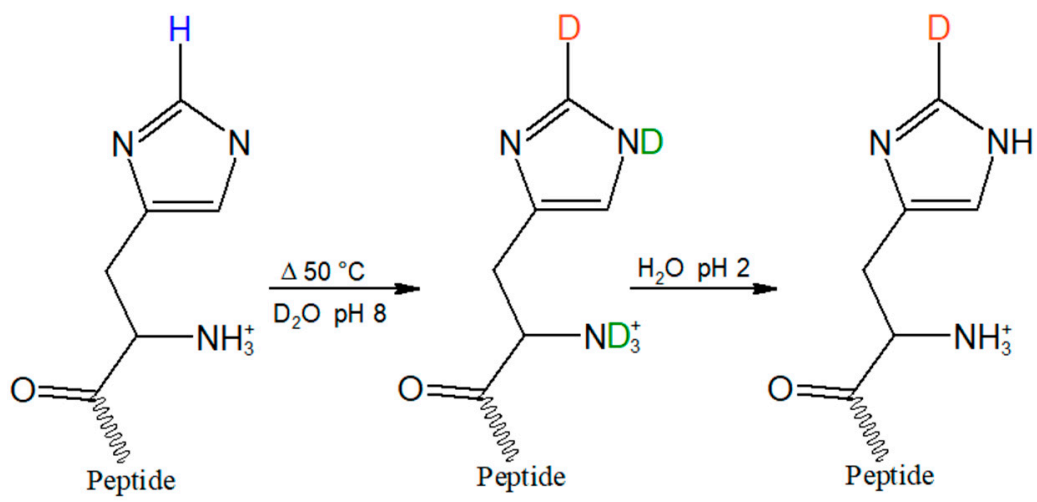

Figure 3. Incorporation of the $\mathrm{C} 2-\mathrm{D}$ probe (orange) on the histidine imidazole ring was achieved by heating the tripeptide in $\mathrm{D}_{2} \mathrm{O}$ for three days at $50{ }^{\circ} \mathrm{C}$ in $\mathrm{D}_{2} \mathrm{O}$ at $\mathrm{pH}$. To back exchange readily exchangeable hydrogens on nitrogen and oxygen (green), the sample was then re-dissolved in $\mathrm{H}_{2} \mathrm{O}$, $\mathrm{pH}$ 2, and lyophilized. 


\section{2. $p$ Ka Determination}

To explore the efficacy of the method of Hoffman et al. in larger peptide sequences, a $10 \mathrm{mM}$ solution in $\mathrm{H}_{2} \mathrm{O}$ of C2-deuterated $\mathrm{HVD}$ was titrated with $\mathrm{NaOD}$ to achieve increments of 0.5 or $0.25 \mathrm{pH}$ units, from $\mathrm{pH} 4.5$ to $\mathrm{pH} 9$, to determine the $\mathrm{pKa}$ of the histidine residue. In the case of the tripeptide, the individual peaks at $2360 \mathrm{~cm}^{-1}$ and $2390 \mathrm{~cm}^{-1}$ were assigned to the neutral and protonated forms of histidine, respectively (Figure 4). It is interesting to note that the C2-D peak corresponding to the deprotonated form of histidine in HVD was shifted by $10 \mathrm{~cm}^{-1}$ from the value previously reported for histidine alone $\left(2350 \mathrm{~cm}^{-1}\right)$ [30]. This shift is perhaps due to differential electrostatic effects associated with the nearby presences of the protonated amino acid terminus and negatively charged carboxyl group in the free amino acid compared to amide bonds in those same positions for the capped peptide.

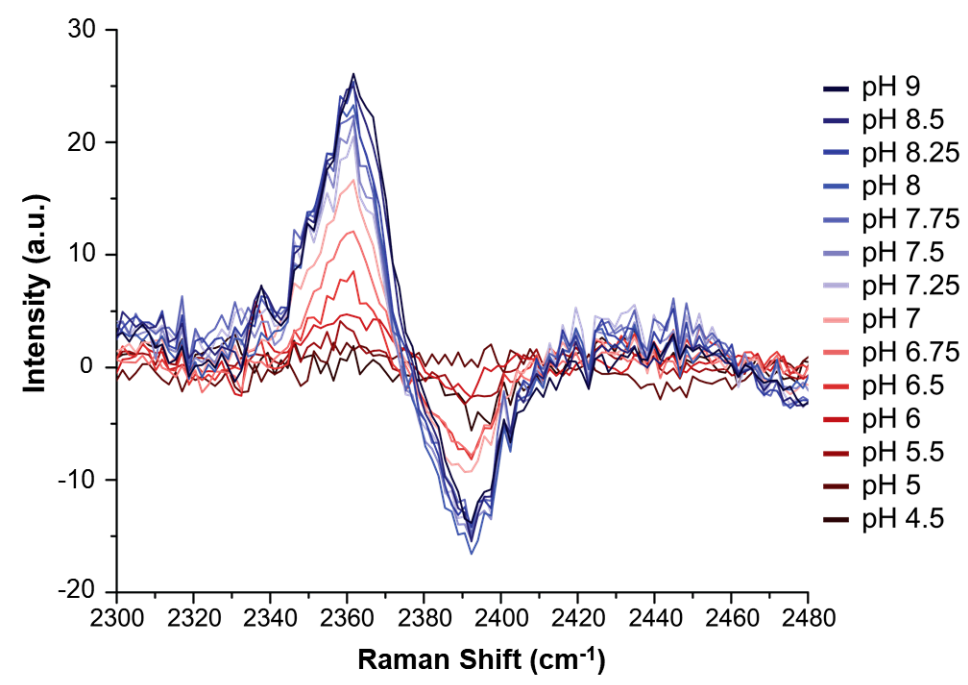

Figure 4. Raman difference spectra of $\mathrm{H}(\mathrm{C} 2-\mathrm{D}) \mathrm{VD}$ peptide at each $\mathrm{pH}$ value, versus the spectrum at $\mathrm{pH}$ 4. More basic samples (from red to blue) display stronger difference spectra up through $\mathrm{pH} 8.25$ (thus indicating the end of the titration).

Although the C2-D signals were present, they were too weak in the Raman spectra to be analyzed directly in the manner described by Hoffman et al. The pKa of HVD was instead determined by creating Raman difference spectra (Figure S3) for each $\mathrm{pH}$ measurement (using the $\mathrm{pH} 4$ spectrum as reference) which were then superimposed (Figure 4). The difference spectra highlight the contrast between the protonated and deprotonated C2-D signals and thereby allow the data to be more readily analyzed. The maximum intensity of the low frequency peak at $2362 \mathrm{~cm}^{-1}$ (where the neutral species grows in) for each difference spectrum was then plotted against $\mathrm{pH}$, and the data were then fitted to a sigmoidal curve (Equation S1). The low frequency peak is higher in intensity than the high frequency peak: this increase in intensity makes this signal more sensitive and easier to analyze (as reported previously in [30]). The midpoint of the resulting sigmoidal curve, which corresponds to the pKa of the histidine residue in the tripeptide, was 6.82 (see Figure 5).

This pKa is slightly higher than that of histidine in solution (ca. 6) [43]. The pKa of histidine can shift depending on the chemical environment of the residue [31]; the difference in pKa value here is thus likely due to the unique chemical environment of this residue in HVD, where among other factors, the histidine residue is in relatively close proximity to aspartic acid. The aspartic acid carboxylate side chain at neutral $\mathrm{pH}$ could stabilize the protonated form of histidine and thus increase its $\mathrm{pKa}$ value.

The pKa determined by Raman difference spectroscopy was confirmed by a ${ }^{1} \mathrm{H}$ NMR titration experiment on non-deuterated peptide under the same conditions. By following the chemical shifts of the hydrogens attached to $C 2$ and $C 4$ of the imidazole ring [36] of the tripeptide, the pKa of histidine in HVD was found to be 6.87 (Figure 6), which is within $0.05 \mathrm{pH}$ units of and statistically identical ( $p=0.95$ assuming Gaussian error) to the pKa determined by Raman spectroscopy. These ${ }^{1} \mathrm{H}$ NMR 
results confirm that Raman spectroscopy is an equally accurate method to determine the pKa of histidine in the peptide.

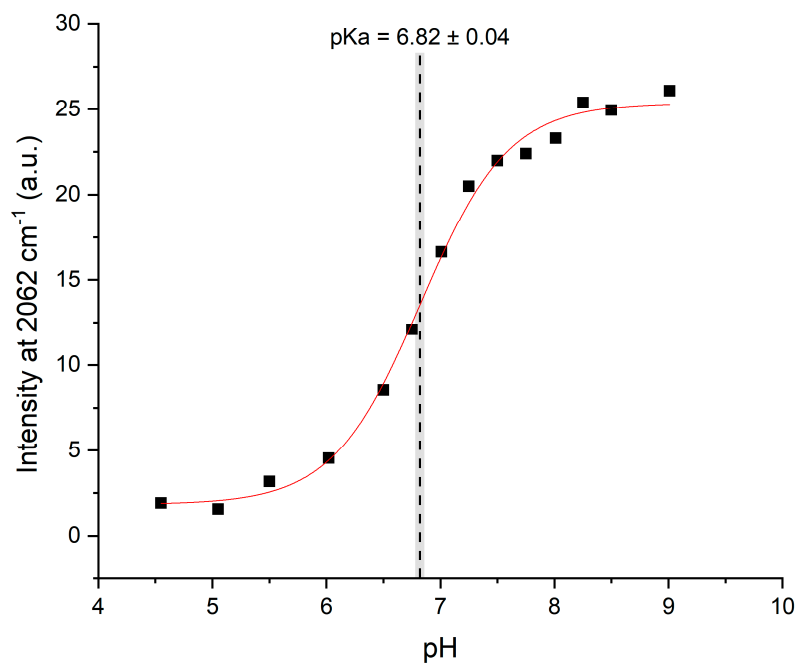

Figure 5. The intensity of the difference spectra at $2362 \mathrm{~cm}^{-1}$ for each titration point vs $\mathrm{pH}$, fitted to a dose-response sigmoidal curve (Equation S1). The gray bar represents the error in the fitted midpoint.

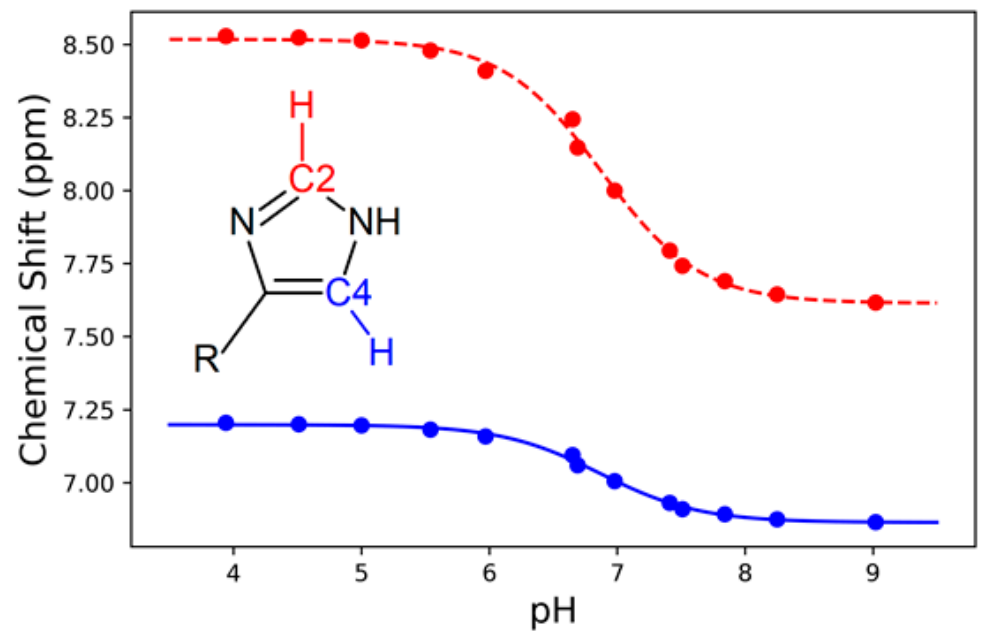

Figure 6. The ${ }^{1} \mathrm{H}$ chemical shift for the hydrogen atoms attached to $\mathrm{C} 2$ (red) and $\mathrm{C} 4$ (blue) of the imidazole ring versus $\mathrm{pH}$, fitted to a dose-response sigmoidal curve (Equation (1)). The average midpoint for the $\mathrm{C} 2$ and $\mathrm{C} 4$ sigmoidal curves yielded a pKa of $6.87 \pm 0.03$.

\section{Discussion}

This study demonstrates clearly that Raman spectroscopy provides a reliable method to determine the pKa of histidine. A method first developed by Hoffman et al. for the determination of the pKa of imidazole is expanded here to demonstrate its utility in peptides. This method provides a particularly compelling means for determining the pKa of histidine in systems where ${ }^{1} \mathrm{H}$ NMR spectroscopy titrations are of limited use, including peptide-based materials that undergo aggregation and/or phase transitions in response to $\mathrm{pH}$ changes (like the parent sequence of the HVD peptide). Such systems include, but are not limited to, various amyloid-forming proteins, such as $\alpha$-synuclein [44-47], and peptide-based materials, such as hydrogels, which have recently been popularized due to their potential medical applications as tissue scaffolds and drug delivery systems $[26,29,48]$. Hydrogels and other soft-matter peptide materials exist at the solid-liquid interface, and as such, Raman spectroscopy offers a flexible method to probe the pKa of histidine in all states of these materials. For most of these examples, ${ }^{1} \mathrm{H}$ NMR spectroscopy is inadequate due to sample constraints, as previously discussed. 
Previous studies noted that other modes of the imidazole ring, particularly C4-C5 $\left(\sim 1600 \mathrm{~cm}^{-1}\right)$ and C4-N3 $\left(\sim 1100 \mathrm{~cm}^{-1}\right)$ stretching, can report on the protonation state of histidine [41]. A possible benefit of the C4-C5 and C4-N3 stretches over C2-D is that they are more intense in the Raman spectrum, and thus the difference spectra used in Figure 5 might not need to be constructed to view these signals. Those regions in the Raman spectrum of HVD were also explored to evaluate if those signals might report on $\mathrm{pKa}$ of histidine in this relatively simple peptide.

A peak at $1115 \mathrm{~cm}^{-1}$ in the Raman spectrum was tentatively assigned to the C4-N3 stretch, but as shown in Figure S1, for this peptide and in contrast to methylimidazole, this signal does not consistently track with changes in $\mathrm{pH}$. The $\mathrm{C} 4-\mathrm{C} 5$ stretch observed at $1580 \mathrm{~cm}^{-1}$ exhibits a more consistent $\mathrm{pH}$-response (Figure 7); however, the data in Figure 7 did not provide as good a fit to a sigmoidal curve (Figure S2). The histidine C4-C5 stretch for HVD is expected to overlap with other C-C stretches within the sequence and/or the peptide's amide II backbone signals [42,49]. Therefore, while there is a relatively clear $\mathrm{pH}$-response from the $\mathrm{C} 4-\mathrm{C} 5$ stretch that appears to report on the histidine protonation state, there may be other signals that also respond to $\mathrm{pH}$ that complicate the interpretability of this spectral region. The C2-D signal, in spite of its weaker intensity, proved to be a more sensitive and direct reporter compared to other possible Raman probes in HVD and is also likely the best candidate for determining the $\mathrm{pKa}$ of histidine in longer peptides or proteins with even more congested vibrational spectra.

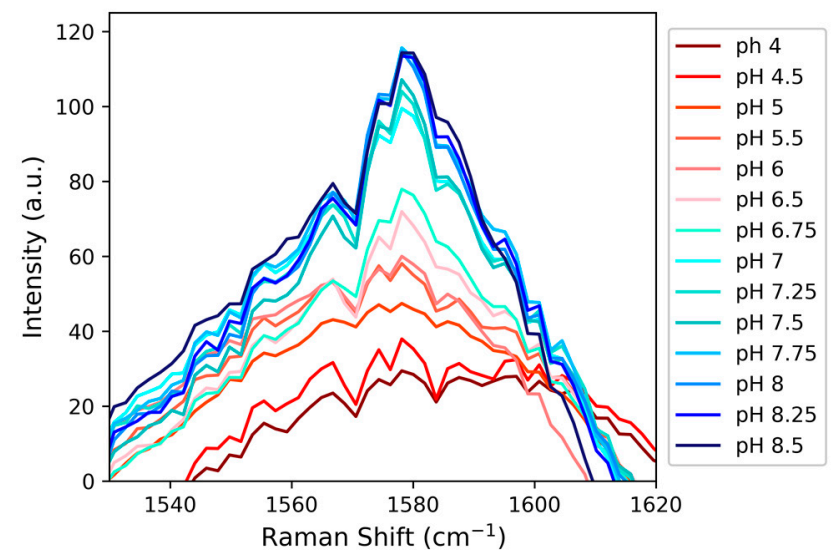

Figure 7. The growth of a peak at $1580 \mathrm{~cm}^{-1}$, circumstantially assigned to the C4-C5 stretch from imidazole (based on prior precedent), as a function of $\mathrm{pH}$ demonstrates that the signal is sensitive to changes in the protonation state of histidine.

While the C2-D Raman probe expands the tool box available to those interested in directly interrogating the $\mathrm{pKa}$ of histidine-containing peptide and protein systems, its general utility will depend to a large extent on its relatively weak signal. We note that in these experiments we are still using a relatively unsophisticated, non-resonant CW-Raman instrument; stimulated Raman or other pulsed-laser techniques with much higher peak powers might expand the applicability of this very specific probe group to lower peptide or protein concentrations and more complicated samples. HVD is the beginning of a 13-amino acid sequence that forms hydrogels, and that sequence is the next target (in both liquid and gelled forms) for this probe technique.

\section{Materials and Methods}

\subsection{Materials}

All solvents and reagents were purchased from commercial suppliers and used without further purification. 
Electrospray mass spectrometry was performed at Haverford College on an Agilent (Santa Clara, CA, USA) 1100 LC/ES Mass Spectrometervia direct infusion of diluted low-pH solutions into the electrospray chamber. See Appendix A.1.

\subsection{Peptide Synthesis and Purification}

The tripeptide $\mathrm{CH}_{3} \mathrm{CONH}-\mathrm{HVD}-\mathrm{CONH}_{2}$ was made by solid phase peptide synthesis using standard Fmoc (N-(9-fluorenyl)methoxycarbonyl) chemistry protocol employing an Applied Biosystems 433A synthesizer (Company, City, State abbreviation if CA or USA, Country). RINK resin (0.1 mmol) (Company, City, State abbreviation if CA or USA, Country) was used to provide a C-terminal carboxamide.

The crude tripeptide was purified by HPLC using a reversed phase $C_{8}$ preparative column. The identity and purity of the resulting peptide was verified by electrospray mass spectrometry (ES MS) with the major peak at $m / z[M+H]=411 \mathrm{amu}$ (Figure S4, top). See Appendix A.1.

\subsection{Deuterium Exchange Reaction}

The tripeptide, $\mathrm{CH}_{3} \mathrm{CONH}-\mathrm{HVD}-\mathrm{CONH}_{2}(8.80 \mathrm{mg} ; 0.0214 \mathrm{mmol})$ was dissolved in $1.5 \mathrm{~mL}$ of deuterium oxide, $\mathrm{D}_{2} \mathrm{O},(99.8 \%)$ in a $2 \mathrm{~mL}$ Eppendorf tube and raised to $\mathrm{pH} 8$ with sodium deuterium oxide $(\mathrm{NaOD}, 40 \%)$ and deuterium chloride $(\mathrm{DCl}, 35 \%)$ and measured with a $\mathrm{pH}$ electrode. The solution was then placed in a $50{ }^{\circ} \mathrm{C}$ water bath for $\sim 72 \mathrm{~h}$, frozen with dry ice, and lyophilized overnight. The resulting white powder was dissolved in $1.5 \mathrm{~mL} 0.01 \mathrm{M}$ hydrochloric acid $(\mathrm{HCl})$ to remove all readily exchangeable residual deuterons, then frozen and lyophilized. The selective incorporation of a single deuterium atom was confirmed by ES MS $(\mathrm{m} / \mathrm{z}$ 412) with disappearance of the peak at $\mathrm{m} / \mathrm{z} 411$, confirming complete exchange (Figure S4).

\subsection{Raman Sample Preparation}

Deuterated tripeptide HVD $(8.80 \mathrm{mg} ; 0.0214 \mathrm{mmol})$ was dissolved in $1.5 \mathrm{~mL}$ water and split into three $0.5 \mathrm{~mL}$ peptide stock solutions. Two of these stock solutions were used for the titration experiment, as explained in more detail below, while the third, of the exact same identity as the other two, was refrigerated as a backup. The titration of the tripeptide occurred over the $\mathrm{pH}$ range of 4.0-9.0, and the $\mathrm{pH}$ was increased by $0.5 \mathrm{pH}$ units, except between $\mathrm{pH} 6.50-8.50$ where the step size was decreased to 0.25 to provide more data near the expected $\mathrm{pKa}$ value. The stock solution was corrected to the desired $\mathrm{pH}$ by adding $0.2-2 \mu \mathrm{L}$ aliquots of $\mathrm{NaOH}$ or $\mathrm{HCl}(0.1-5 \mathrm{M})$, as needed. After the desired $\mathrm{pH}$ was achieved, a sample for Raman spectroscopy was prepared by placing approximately $5 \mu \mathrm{L}$ of solution into a $1 \mathrm{~mm}$ glass capillary tube. This process of correcting the $\mathrm{pH}$ of the stock solution and preparing the Raman sample was repeated for the duration of the titration. To prevent the concentration of the samples from changing by more than $5 \%$, one peptide stock solution was used for the first half of the titration experiment and a second stock solution was used for the remaining $\mathrm{pH}$ points.

\subsection{Raman Spectroscopy}

Raman scattering experiments were performed with a home-built continuous wave Raman spectrometer reported previously [30] but with modification since that initial report. The excitation source here was a Cobolt, Inc. DPSS $532 \mathrm{~nm}$ laser attenuated to incident power of $200 \mathrm{~mW}$. Samples were loaded into $1 \mathrm{~mm}$ glass capillary tubes (held at a constant temperature of $22^{\circ} \mathrm{C}$ using a home-built circulating sample holder) and excited vertically across the width of the tubes. Scattered light was collected at $90^{\circ}$ to the incident excitation beam via a Nikon camera lens, focused into a SpectraPro $0.5 \mathrm{~m}$ monochromator (using a 600 grooves $/ \mathrm{mm}$ grating blazed at $500 \mathrm{~nm}$ ), and collected on a PI-Acton Spec10/100 liquid $\mathrm{N}_{2}$-cooled CCD camera (Figure S5). Data was collected with the camera centered at $603 \mathrm{~nm}$ over a period of $12 \mathrm{~h}$ in accumulations of $1 \mathrm{~min}$. No obvious sample degradation was observed 
under these conditions, as monitored via comparisons of other regions of the Raman spectrum under lower laser power and shorter exposure times.

\subsection{Raman Data Processing}

All spectra were processed by first subtracting a $\mathrm{H}_{2} \mathrm{O}$ background spectrum normalized to match the intensity of the $\mathrm{OH}$ stretching band. Difference spectra were achieved by subtracting the $\mathrm{pH} 4$ HVD standard spectrum from every subsequent spectrum collected (Figure S3). The pH-invariant C-H Raman stretch at $2950 \mathrm{~cm}^{-1}$ was used to normalize peak intensities for the peptide in both spectra. The baseline of the difference spectrum was then smoothed by fitting the data from $2270 \mathrm{~cm}^{-1}$ to $2420 \mathrm{~cm}^{-1}$ to a $3^{\text {rd }}$ degree polynomial and subtracting this fitted line from the data to achieve a final difference spectrum, which results in some sections of the Raman spectrum appearing to have negative intensities/partially dispersive lineshapes due to the polynomial nature of the baseline fit near the actual C2-D stretching signals.

The difference spectra were then overlaid, and the maximum peak intensity at $2362 \mathrm{~cm}^{-1} \mathrm{of}$ each difference spectrum was plotted versus $\mathrm{pH}$. This data was then fit to a sigmoidal dose-response curve (Equation (1)). The pKa was extracted from the data by finding the midpoint $\left(\log x_{0}\right)$ of this sigmoidal curve from its equation. (The $p$ parameter here is the Hill-type "slope" or "cooperativity" parameter and does not influence the midpoint, which is different from the " $p$ " probability measure mentioned above when comparing experimentally determined midpoints.)

$$
y=A_{1}+\frac{\left(A_{2}-A_{1}\right)}{1+10^{\left(\log \left(x_{0}\right)-x\right) * p}}
$$

\section{7. ${ }^{1}$ H NMR Spectroscopy}

${ }^{1} \mathrm{H}$ NMR spectroscopy samples were $1 \mathrm{mM}$ of $\mathrm{HVD}$ in $\mathrm{ddH}_{2} \mathrm{O}$ doped with $10 \% \mathrm{D}_{2} \mathrm{O}$ and $0.1 \%$ 4,4-dimethyl-4-silapentane-1-sulfonic acid (DSS) as a chemical shift standard. Experiments were performed in a quartz tube at $25^{\circ} \mathrm{C}$ using an Agilent VNMRS DirectDrive (Agilent, Santa Clara, CA, USA) spectrometer at Lund University, Sweden operating at a ${ }^{1} \mathrm{H}$ frequency of $600 \mathrm{MHz}$. The chemical shifts of the histidine C2 and C4 hydrogens were monitored via $131 \mathrm{D}^{1} \mathrm{H}$ spectra acquired over the $\mathrm{pH}$ range from 3.2 to 9.0. Spectra were recorded with 16 scans and a total acquisition time of $1 \mathrm{~min}$. Residual water was suppressed by steady state pulses. Spectra were processed with iNMR (Nucleomatica, Molfetta, Italy).

Supplementary Materials: The following are available online, Equation S1: Dose-response curve fit, Figure S1: Raman spectra of C4-N3 stretching region, Figure S2: Dose-response curve fit for C4-C5 stretching region, Figure S3: Difference spectrum construction, Figure S4: ES MS spectra of H(C2-D)VD, Figure S5: CW Raman spectrometer schematic.

Author Contributions: Conceptualization, K.S.Å., C.H.L., and B.H.P.; methodology, K.S.Å., C.H.L., and B.H.P.; validation, A.M., K.S.Å., C.H.L., and B.H.P.; investigation, A.M., and B.H.P.; resources, K.S.Å., C.H.L., and A.M.; data curation, B.H.P.; writing-original draft preparation, B.H.P.; writing-review and editing, A.M., K.S.A., C.H.L., and B.H.P.; visualization, B.H.P.; supervision, K.S.A., and C.H.L.; project administration, K.S.A., and C.H.L.; funding acquisition, K.S.Å., C.H.L.

Funding: This research was funded by NSF Division of Chemistry MSN (Macromolecular, Supramolecular and Nanochemistry), program grant CHE-1609291 to K.S.A.., and by NSF Division of Chemistry CSDM-A (Chemical Structure, Dynamics, and Mechanisms) program grants CHE-1150727 and CHE-1800080 to C.H.L, as well as a Henry Dreyfus Teacher-Scholar Award to C.H.L.

Acknowledgments: The authors would like to acknowledge Chuhui Fu, Caroline McKeon, and Samuel Epstein for their assistance with Raman data collection and processing, as well as Axel Rüter and Anja Holzheu for help with data visualization. Lastly, the authors would like to acknowledge Kaiwei Wang for help with purifying and synthesizing the HVD peptide.

Conflicts of Interest: The authors declare no conflict of interest. 


\section{Appendix A}

\section{Appendix A.1 Materials}

Acetonitrile $\left(\mathrm{CH}_{3} \mathrm{CN}\right), \mathrm{MeOH}$, and $\mathrm{N}, \mathrm{N}$-dimethylformamide (DMF) were purchased from Pharmco-AAPER. Trifluoroacetic acid (TFA) (99\%), piperidine (95+\%), thioanisole (99\%), anisole (anhydrous, 99.7\%), triethylamine (anhydrous, 99\%), dicholordimethylsaline (99.5\%), 1,4-dioxane (anhydrous, 99.8\%), petroleum ether (bp: $30-60{ }^{\circ} \mathrm{C}$ ), piperazine $(99 \%)$, trityl chloride $(97 \%)$, Fmoc chloride $(97 \%)$, DBU $(98 \%)$, 1,2-ethanedithiol $(90+\%)$, and deuterium chloride, $\left(35 \%\right.$ wt in $\mathrm{D}_{2} \mathrm{O}$, 99 atom \% D) were purchased form Sigma-Aldrich. NaOD ( $40 \%$ wt in $\mathrm{D}_{2} \mathrm{O}, 99$ atom \% D), $1 \mathrm{~mL}$ ampules of $\mathrm{CD}_{3} \mathrm{COOD}(\mathrm{D}, 99.9 \%), 1 \mathrm{~mL}$ ampules of $\mathrm{CD}_{3} \mathrm{~S}(\mathrm{O}) \mathrm{CD}_{3}(\mathrm{D}, 99.9 \%)$, and $50 \mathrm{~g}$ of $\mathrm{CH}_{3} \mathrm{OD}(\mathrm{D}, 99 \%)$ were purchased from Cambridge Isotope Laboratories. $N$-methylpyrrolidone (NMP) was purchased from BioRad labs. The O-(benzotriazol-1-yl)- $N, N, N^{\prime} N^{\prime}$-tetramethyluronium hexafluorophosphate (HBTU), 1-hydroxybenzotriazole hydrate (HOBt hydrate), and all of the Fmoc protected amino acids were purchased from Advanced Chem Tech. The amide Rink resin was purchased from Chem Pep.

\section{Appendix A.2 Peptide Synthesis and Purification}

To synthesize $\mathrm{CH}_{3} \mathrm{CONH}-\mathrm{HVD}-\mathrm{CONH}_{2}$, RINK resin $(0.1 \mathrm{mmol})$ was used to provide a C-terminal carboxamide. The carboxylic acid of the amino acid added was activated with a 1:1 stoichiometric mixture of $O$-benzotriazole- $N, N, N^{\prime}, N^{\prime}$-tetramethyluronium hexafluorophosphate (HBTU) and $N$-hydroxybenzotriazole (HOBt). All amino acid residues were double coupled with each coupling reaction containing $1 \mathrm{mmol}$ (10 eqv) of the respective amino acid. After the peptide was synthesized, it was $N$-acetylated with a solution of $0.5 \mathrm{M}$ acetic anhydride, $0.125 \mathrm{M}$ $N, N$-diisopropylethylamine (DIEA), and 0.015 M HOBt in N-methyl-2-pyrrolidone (NMP). The peptide was then cleaved from the resin with TFA/thioanisole/1,2-ethanedithiol/anisole $(v / v)$ 9.0:0.5:0.3:0.2 $(5.0 \mathrm{~mL})$ for $2 \mathrm{~h}$ at ambient temperature. The cleavage solution was then concentrated with a stream of $\mathrm{N}_{2}$ gas to a volume of approximately $1 \mathrm{~mL}$, and the crude peptide was precipitated with the addition of ice-cold diethyl ether. The precipitated peptide was collected by filtration through a fine sintered glass funnel, re-dissolved in water and acetonitrile, and lyophilized. The crude tripeptide was purified by HPLC using a reversed phase $C_{8}$ preparative column (Vydac, cat. \# 208TP1022). The peptide was first dissolved in $1: 1 \mathrm{CH}_{3} \mathrm{CN}: \mathrm{H}_{2} \mathrm{O}$ at a concentration of $5 \mathrm{mg} / \mathrm{mL}$ with $50 \mathrm{mg}$ of guanidine thiocyanate (1000 wt.\%). The peptide was purified in $500 \mu \mathrm{L}$ injections with $0.1 \%$ trifluoracetic acid (TFA) in water (solvent A) and 0.1\% TFA in $\mathrm{CH}_{3} \mathrm{CN}: \mathrm{H}_{2} \mathrm{O}$ 9:1 (solvent $\mathrm{B}$ ) employing a linear gradient of 0-20\% solvent $\mathrm{B}$ over $20 \mathrm{~min}$ ( $1 \%$ increase in solvent $\mathrm{B} / \mathrm{min})$.

\section{References}

1. Adhikary, R.; Zimmermann, J.; Romesberg, F.E. Transparent Window Vibrational Probes for the Characterization of Proteins with High Structural and Temporal Resolution. Chem. Rev. 2017, 117, 1927-1969. [CrossRef] [PubMed]

2. Kim, H.; Cho, M. Infrared Probes for Studying the Structure and Dynamics of Biomolecules. Chem. Rev. 2013, 113, 5817-5847. [CrossRef] [PubMed]

3. Ma, J.; Pazos, I.M.; Zhang, W.; Culik, R.M.; Gai, F. Site-Specific Infrared Probes of Proteins. Annu. Rev. Phys. Chem. 2015, 66, 357-377. [CrossRef] [PubMed]

4. Rostron, P.; Garber, D.; Gaber, S. Raman Spectroscopy, a review. Int. J. Eng. Tech. Res. 2016, 6, 50-64.

5. Chin, J.K.; Jimenez, R.; Romesberg, F.E. Direct Observation of Protein Vibrations by Selective Incorporation of Spectroscopically Observable Carbon-Deuterium Bonds in Cytochrome c. J. Am. Chem. Soc. 2001, 123, 2426-2427. [CrossRef] [PubMed]

6. Thielges, M.C.; Case, D.A.; Romesberg, F.E. Carbon-Deuterium Bonds as Probes of Dihydrofolate Reductase. J. Am. Chem. Soc. 2008, 130, 6597-6603. [CrossRef] [PubMed]

7. Noether, H.D. Infra-Red and Raman Spectra of Polyatomic Molecules XVII. Methyl-d3-Alcohol-d and Methyl-d3-Alcohol. J. Chem. Phys. 1942, 10, 693-699. [CrossRef] 
8. Neelakantan, P.; Krishnan, R.S.; Iitaka, Y. Raman spectrum of C-deuterated $\gamma$-glycine $\left(\mathrm{NH}_{3}{ }^{+} \mathrm{CD}_{2} \mathrm{COO}^{-}\right)$. Proc. Indian Acad. Sci. Sect. A 1963, 58, 275-278. [CrossRef]

9. Sunder, S.; Mendelsohn, R.; Bernstein, H.J. Raman studies of the C-H and C-D stretching regions in stearic acid and some specifically deuterated derivatives. Chem. Phys. Lipids 1976, 17, 456-465. [CrossRef]

10. Bulkin, B.J.; Krishnamachari, N. Vibrational spectra of liquid crystals. IV. Infrared and Raman spectra of phospholipid-water mixtures. J. Am. Chem. Soc. 1972, 94, 1109-1112. [CrossRef]

11. Bulkin, B.J.; Krishnan, K. Vibrational spectra of liquid crystals. III. Raman spectra of crystal, cholesteric, and isotropic cholesterol esters, 2800-3100-cm-1region. J. Am. Chem. Soc. 1971, 93, 5998-6004. [CrossRef]

12. Larsson, K. Conformation-dependent features in the raman spectra of simple lipids. Chem. Phys. Lipids 1973, 10, 165-176. [CrossRef]

13. Larsson, K.; Rand, R.P. Detection of changes in the environment of hydrocarbon chains by raman spectroscopy and its application to lipid-protein systems. Biochim. Biophys. Acta BBA Lipids Lipid Metab. 1973, 326, 245-255. [CrossRef]

14. Gaber, B.P.; Peticolas, W.L. On the quantitative interpretation of biomembrane structure by Raman spectroscopy. Biochim. Biophys. Acta BBA Biomembr. 1977, 465, 260-274. [CrossRef]

15. Snyder, R.G.; Hsu, S.L.; Krimm, S. Vibrational spectra in the C-H stretching region and the structure of the polymethylene chain. Spectrochim. Acta Part Mol. Spectrosc. 1978, 34, 395-406. [CrossRef]

16. Snyder, R.G.; Scherer, J.R. Band structure in the C-H stretching region of the Raman spectrum of the extended polymethylene chain: Influence of Fermi resonance. J. Chem. Phys. 1979, 71, 3221-3228. [CrossRef]

17. Nakamizo, M.; Kammereck, R.; Walker, P.L. Laser raman studies on carbons. Carbon 1974, 12, $259-267$. [CrossRef]

18. Kitson, R.E.; Griffith, N.E. Infrared Absorption Band Due to Nitrile Stretching Vibration. Anal. Chem. 1952, 24, 334-337. [CrossRef]

19. Ulrich, H. Cumulenes in Click Reactions; Wiley-Interscience: Chichester, UK, 2009.

20. Sum, A.K.; Burruss, R.C.; Sloan, E.D. Measurement of Clathrate Hydrates via Raman Spectroscopy. J. Phys. Chem. B 1997, 101, 7371-7377. [CrossRef]

21. Wang, Y.; Huang, W.E.; Cui, L.; Wagner, M. Single cell stable isotope probing in microbiology using Raman microspectroscopy. Curr. Opin. Biotechnol. 2016, 41, 34-42. [CrossRef]

22. Wei, L.; Yu, Y.; Shen, Y.; Wang, M.C.; Min, W. Vibrational imaging of newly synthesized proteins in live cells by stimulated Raman scattering microscopy. Proc. Natl. Acad. Sci. USA 2013, 110, 11226-11231. [CrossRef] [PubMed]

23. Kubryk, P.; Kölschbach, J.S.; Marozava, S.; Lueders, T.; Meckenstock, R.U.; Niessner, R.; Ivleva, N.P. Exploring the Potential of Stable Isotope (Resonance) Raman Microspectroscopy and Surface-Enhanced Raman Scattering for the Analysis of Microorganisms at Single Cell Level. Anal. Chem. 2015, 87, 6622-6630. [CrossRef] [PubMed]

24. Berry, D.; Mader, E.; Lee, T.K.; Woebken, D.; Wang, Y.; Zhu, D.; Palatinszky, M.; Schintlmeister, A.; Schmid, M.C.; Hanson, B.T.; et al. Tracking heavy water (D2O) incorporation for identifying and sorting active microbial cells. Proc. Natl. Acad. Sci. USA 2015, 112, E194-E203. [CrossRef] [PubMed]

25. Miller, C.S.; Corcelli, S.A. Carbon-Deuterium Vibrational Probes of the Protonation State of Histidine in the Gas-Phase and in Aqueous Solution. J. Phys. Chem. B 2010, 114, 8565-8573. [CrossRef] [PubMed]

26. Frohm, B.; DeNizio, J.E.; Lee, D.S.; Gentile, L.; Olsson, U.; Malm, J.; Åkerfeldt, K.S.; Linse, S. A peptide from human semenogelin I self-assembles into a pH-responsive hydrogel. Soft Matter 2015, 11, 414-421. [CrossRef] [PubMed]

27. Schmaljohann, D. Thermo- and $\mathrm{pH}$-responsive polymers in drug delivery. Adv. Drug Deliv. Rev. 2006, 58, 1655-1670. [CrossRef] [PubMed]

28. Stuart, M.A.C.; Huck, W.T.S.; Genzer, J.; Müller, M.; Ober, C.; Stamm, M.; Sukhorukov, G.B.; Szleifer, I.; Tsukruk, V.V.; Urban, M.; et al. Emerging applications of stimuli-responsive polymer materials. Nat. Mater. 2010, 9, 101-113. [CrossRef]

29. Dasgupta, A.; Mondal, J.H.; Das, D. Peptide hydrogels. RSC Adv. 2013, 3, 9117-9149. [CrossRef]

30. Hoffman, K.W.; Romei, M.G.; Londergan, C.H. A New Raman Spectroscopic Probe of Both the Protonation State and Noncovalent Interactions of Histidine Residues. J. Phys. Chem. A 2013, 117, 5987-5996. [CrossRef] 
31. Liu, T.; Ryan, M.; Dahlquist, F.W.; Griffith, O. Hayes Determination of pKa values of the histidine side chains of phosphatidylinositol-specific phospholipase $C$ from Bacillus cereus by NMR spectroscopy and site-directed mutagenesis. Protein Sci. 2008, 6, 1937-1944. [CrossRef]

32. Hansen, A.L.; Kay, L.E. Measurement of histidine $\mathrm{pKa}$ values and tautomer populations in invisible protein states. Proc. Natl. Acad. Sci. USA 2014, 111, E1705-E1712. [CrossRef] [PubMed]

33. Bartik, K.; Redfield, C.; Dobson, C.M. Measurement of the individual pKa values of acidic residues of hen and turkey lysozymes by two-dimensional ${ }^{1} \mathrm{H}$ NMR. Biophys. J. 1994, 66, 1180-1184. [CrossRef]

34. Bundi, A.; Wüthrich, K. ${ }^{1} \mathrm{H}-\mathrm{nmr}$ parameters of the common amino acid residues measured in aqueous solutions of the linear tetrapeptides H-Gly-Gly-X-L-Ala-OH. Biopolymers 1979, 18, 285-297. [CrossRef]

35. Frassineti, C.; Ghelli, S.; Gans, P.; Sabatini, A.; Moruzzi, M.S.; Vacca, A. Nuclear Magnetic Resonance as a Tool for Determining Protonation Constants of Natural Polyprotic Bases in Solution. Anal. Biochem. 1995, 231, 374-382. [CrossRef] [PubMed]

36. Markley, J.L. Observation of histidine residues in proteins by nuclear magnetic resonance spectroscopy. Acc. Chem. Res. 1975, 8, 70-80. [CrossRef]

37. Sachs, D.H.; Schechter, A.N.; Cohen, J.S. Nuclear Magnetic Resonance Titration Curves of Histidine Ring Protons, I. Influence of Neighboring Charged Groups. J. Biol. Chem. 1971, 246, 6576-6580. [PubMed]

38. Henchoz, Y.; Schappler, J.; Geiser, L.; Prat, J.; Carrupt, P.A.; Veuthey, J.L. Rapid determination of pKa values of 20 amino acids by CZE with UV and capacitively coupled contactless conductivity detections. Anal. Bioanal. Chem. 2007, 389, 1869-1878. [CrossRef] [PubMed]

39. Včeláková, K.; Zusková, I.; Kenndler, E.; Gaš, B. Determination of cationic mobilities and pKa values of 22 amino acids by capillary zone electrophoresis. Electrophoresis 2004, 25, 309-317. [CrossRef]

40. Zscherp, C.; Schlesinger, R.; Tittor, J.; Oesterhelt, D.; Heberle, J. In situ determination of transient pKa changes of internal amino acids of bacteriorhodopsin by using time-resolved attenuated total reflection Fourier-transform infrared spectroscopy. Proc. Natl. Acad. Sci. USA 1999, 96, 5498-5503. [CrossRef]

41. Hasegawa, K.; Ono, T.; Noguchi, T. Vibrational Spectra and Ab Initio DFT Calculations of 4-Methylimidazole and Its Different Protonation Forms: Infrared and Raman Markers of the Protonation State of a Histidine Side Chain. J. Phys. Chem. B 2000, 104, 4253-4265. [CrossRef]

42. Ashikawa, I.; Itoh, K. Raman spectra of polypeptides containing L-histidine residues and tautomerism of imidazole side chain. Biopolymers 1979, 18, 1859-1876. [CrossRef]

43. Walba, H.; Isensee, R.W. Acidity Constants of Some Arylimidazoles and Their Cations. J. Org. Chem. 1961, 26, 2789-2791. [CrossRef]

44. Kumar, R.; Das, S.; Mohite, G.M.; Rout, S.K.; Halder, S.; Jha, N.N.; Ray, S.; Mehra, S.; Agarwal, V.; Maji, S.K. Cytotoxic Oligomers and Fibrils Trapped in a Gel-like State of $\alpha$-Synuclein Assemblies. Angew. Chem. Int. Ed. 2018, 57, 5262-5266. [CrossRef] [PubMed]

45. Semerdzhiev, S.A.; Shvadchak, V.V.; Subramaniam, V.; Claessens, M.M.A.E. Non-uniform self-assembly: On the anisotropic architecture of $\alpha$-synuclein supra-fibrillar aggregates. Sci. Rep. 2017, 7, 7699. [CrossRef] [PubMed]

46. Jean, L.; Foley, A.C.; Vaux, D.J.T. The Physiological and Pathological Implications of the Formation of Hydrogels, with a Specific Focus on Amyloid Polypeptides. Biomolecules 2017, 7, 70. [CrossRef] [PubMed]

47. Buell, A.K.; Galvagnion, C.; Gaspar, R.; Sparr, E.; Vendruscolo, M.; Knowles, T.P.J.; Linse, S.; Dobson, C.M. Solution conditions determine the relative importance of nucleation and growth processes in $\alpha$-synuclein aggregation. Proc. Natl. Acad. Sci. USA 2014, 111, 7671-7676. [CrossRef] [PubMed]

48. Altunbas, A.; Lee, S.J.; Rajasekaran, S.A.; Schneider, J.P.; Pochan, D.J. Encapsulation of curcumin in self-assembling peptide hydrogels as injectable drug delivery vehicles. Biomaterials 2011, 32, 5906-5914. [CrossRef]

49. Alix, A.J.P.; Pedanou, G.; Berjot, M. Fast determination of the quantitative secondary structure of proteins by using some parameters of the Raman Amide I band. J. Mol. Struct. 1988, 174, 159-164. [CrossRef]

Sample Availability: Samples of the compounds are not available from the authors. 